\title{
HtrA-mediated E-cadherin cleavage is limited to DegP and DegQ homologs expressed by gram-negative pathogens
}

\author{
Carmen M. Abfalter ${ }^{\dagger}$, Maria Schubert ${ }^{\dagger}$, Camilla Götz, Thomas P. Schmidt, Gernot Posselt and Silja Wessler ${ }^{*}$ (i)
}

\begin{abstract}
Background: The serine proteases HtrA/DegP secreted by the human gastrointestinal pathogens Helicobacter pylori (H. pylori) and Campylobacter jejuni (C. jejuni) cleave the mammalian cell adhesion protein E-cadherin to open intercellular adhesions. A wide range of bacteria also expresses the HtrA/DegP homologs DegQ and/or DegS, which significantly differ in structure and function.

Methods: E-cadherin shedding was investigated in infection experiments with the Gram-negative pathogens $\mathrm{H}$. pylori, enteropathogenic Escherichia coli (EPEC), Salmonella enterica subsp. Enterica (S. Typhimurium), Yersinia enterocolitica (Y. enterocolitica), and Proteus mirabilis (P. mirabilis), which express different combinations of HtrAs. Annotated wild-type $h t r A / \operatorname{deg} P, \operatorname{deg} Q$ and $\operatorname{deg} S$ genes were cloned and proteolytically inactive mutants were generated by a serine-to-alanine exchange in the active center. All HtrA variants were overexpressed and purified to compare their proteolytic activities in casein zymography and in vitro E-cadherin cleavage experiments.

Results: Infection of epithelial cells resulted in a strong E-cadherin ectodomain shedding as reflected by the loss of full length E-cadherin in whole cell lysates and formation of the soluble $90 \mathrm{kDa}$ extracellular domain of E-cadherin (NTF) in the supernatants of infected cells. Importantly, comparing the caseinolytic and E-cadherin cleavage activities of HtrA/DegP, DegQ and DegS proteins revealed that DegP and DegQ homologs from H. pylori, S. Typhimurium, Y. enterocolitica, EPEC and P. mirabilis, but not activated DegS, cleaved E-cadherin as a substrate in vitro.
\end{abstract}

Conclusions: These data indicate that E-cadherin cleavage is confined to HtrA/DegP and DegQ proteins representing an important prevalent step in bacterial pathogenesis.

Keywords: HtrA, DegP, DegQ, E-cadherin

\section{Background}

Human pathogens developed sophisticated strategies to survive and colonize under extreme conditions or to conquer host defense mechanisms. The serine proteases HtrA/DegP are important key players in protein quality control and stress response through refolding and degrading misfolded proteins in the periplasm of bacteria $[1,2]$. In $E$. coli, DegP was identified as an ATPindependent heat shock protease that maintains protein

\footnotetext{
* Correspondence: silja.wessler@sbg.ac.at

${ }^{\dagger}$ Equal contributors

Division of Microbiology, Department of Molecular Biology, Paris-Lodron University of Salzburg, Billroth Str. 11, A-5020 Salzburg, Austria
}

homeostasis in the periplasm by combining chaperone and protease activities. DegP consists of an N-terminal signal peptide, which is responsible for its periplasmic localization followed by a conserved chymotrypsin-like protease domain harboring the catalytic triad composed of a histidine, a serine and an aspartate residue. In the C-terminal region, DegP contains two flexible PDZ (postsynaptic density protein [PSD95], Drosophila disc large tumor suppressor [Dlg1], and zonula occludens-1 protein $[\mathrm{ZO}-1])$ domains mediating protein-protein interactions, substrate recognition and substrate binding $[1,3,4]$. The monomeric E. coli DegP can form trimers, hexamers, dodecamers, and finally active 24-mers [5, 6]. It was demonstrated that binding of hexameric DegP to 
misfolded proteins leads to the formation of active 12mers and 24-mers [5]. Several substrates for E. coli DegP were described, including maltose binding protein, alkaline phosphatase, $\alpha$-amylase, outer membrane protein OmpF and OmpC, the pilin subunit PapA or the acylated precursor of colicin A lysis protein [2]. E. coli also expresses the HtrA/DegP homologs DegQ (HhoA, HtrA homolog A) and DegS (HhoB, HtrA homolog B). The main difference between DegP and DegQ is the length of the N-terminally positioned LA loop, which lacks 20 amino acids in DegQ $[7,8]$. The LA loop is implicated in the stabilization of the inactive hexameric conformation of DegP [9]. Although DegQ and DegP exhibit $\sim 60 \%$ sequence identity, it is not fully understood whether they share overlapping function. It was shown that DegQ is capable of rescuing temperature sensitive $\operatorname{deg} P$-negative strains [10], while others have postulated that the substrate specificity of DegQ might be different since DegQ re-expression could not fully restore the phenotype of a $\operatorname{deg} P$ knock-out mutant $[8,11]$. DegS is considered as a regulatory protease targeting the antisigma factor RseA in the periplasm, which is implicated in sensing protein folding stress. After detecting misfolded outer membrane proteins, DegS processes the anti-sigma factor RseA, which is followed by RseP cleavage. As a regulated intramembrane proteolysis cascade, this leads to the sigma-E-mediated expression of factors involved in protein folding stress in the periplasm and assembly of outer membrane proteins $[3,12]$.

In many pathogenic bacteria, HtrA promotes virulence as reflected by the observation that htrA knock-out mutants show either an apathogenic phenotype or a significantly reduced virulence $[2,13]$. A widespread explanation for the HtrA-dependent pathogenesis arose from the observation that HtrA increases bacterial survival under stress conditions during infection. Further, it was suggested that HtrA is involved in the processing of outer membrane (virulence) factors [13]. For instance, DegP was identified as a critical factor for IcsA (VirG) surface presentation in Shigella flexneri (S. flexneri) [14]. Furthermore, reduced adherence of a $C$. jejuni htrA knock-out mutant was observed in vitro [15-18] suggesting that the expression of adhesins might be downregulated. However, in a mouse model for $C$. jejuni infections, isogenic htrA-negative bacteria colonized equally well, while host cell apoptosis and the proinflammatory immune responses were significantly attenuated $[19,20]$. Similar observations were made for a number of other htrA-negative pathogens in vivo (e.g. Yersinia pestis, Streptococcus pneumoniae, Mycobacterium tuberculosis, Listeria monocytogenes, Klebsiella pneumoniae, etc.) [13, 21]. In Chlamydia trachomatis (C. trachomatis) HtrA functions as an active chaperone and serine protease [22]. HtrA is secreted from chlamydial inclusions into the host cytoplasm independently of the type-III secretion system [23] and exhibits a critical role in the replicative phase of the chlamydial developmental cycle [24]. These data underline the crucially important role of HtrA in bacterial pathogenesis. However, the molecular mechanism remained largely unknown.

An additional function of HtrA in several Gramnegative pathogens of the gastrointestinal tract was recently described. During infection with $H$. pylori and $C$. jejuni, HtrA is secreted into the microenvironment $[25,26]$ and was detected in outer membrane vesicles (OMVs) [27, 28]. H. pylori and C. jejuni HtrAs cleave-off the extracellular domain of the cell adhesion protein E-cadherin on epithelial cells [15, 27, 29, 30]. E-cadherin is an important key molecule in the establishment and maintenance of an intact epithelial barrier. Consequently, E-cadherin cleavage disrupts the barrier function and allows bacterial entry into the intercellular space and transmigration [31, 32]. In $H$. pylori or C. trachomatis, genomic htrA deletions mutants could not be generated so far. However, functional small molecule inhibitors and substrate-derived peptide inhibitors were designed which efficiently blocked HtrA functions [30, 33, 34]. HtrA-mediated E-cadherin cleavage was also shown for EPEC and S. flexneri supporting our hypothesis that E-cadherin ectodomain shedding might be a prevalent mechanism for pathogenic bacteria to promote virulence through the interference with (baso-) lateral domains of epithelial cells [15]. However, these studies were restricted to HtrA/DegP and the role of DegQ and DegS in E-cadherin cleavage was not considered so far. In this report, we investigated E-cadherin shedding in response to infection with the Gram-negative gastrointestinal pathogens $H$. pylori, EPEC, Y. enterocolitica, S. enterica subsp. Enterica ( $S$. Typhimurium) and the uropathogenic bacterium $P$. mirabilis, which express different combinations of HtrA proteins.

\section{Methods}

\section{Infection experiments}

MKN-28 and NCI-N87 cells were grown in RPMI 1640 medium (Sigma Aldrich) containing 10\% FBS (Sigma Aldrich) in 6-well plates to a confluency of 70 to $80 \%$ for 2 days. $16 \mathrm{~h}$ prior to the infection, medium was replaced by serum-free RPMI 1640. H. pylori (Hp26695) was cultivated on GC-Agar plates containing 10\% horse serum under microaerophilic conditions (CampiGen, Thermo Scientific) at $37{ }^{\circ} \mathrm{C}$ for 2 days. P. mirabilis (ATCC 29906) was grown on nutrient agar, and EPEC (E2348), Salmonella enterica subsp. Enterica ( $S$. Typhiumurium, NCTC 12023) and Y. enterocolitica (ATCC 27729) were cultivated on LB agar plates for $24 \mathrm{~h}$ at $37{ }^{\circ} \mathrm{C}$. Serum- 
starved cells were infected at a multiplicity of infection (MOI) of 100 with $H$. pylori, at a MOI 5 with EPEC or $S$. Typhimurium, at a MOI 50 with $Y$. enterocolitica and at a MOI 2 with $P$. mirabilis. Cells were harvested after indicated time periods in lysis buffer $(20 \mathrm{mM}$ Tris $\mathrm{pH} 7.5$, $1 \mathrm{mM}$ EDTA, $100 \mathrm{mM} \mathrm{NaCl}, 1 \%$ Triton X-100, 0.5\% DOC, $0.1 \%$ SDS, $0.5 \%$ NP-40). Samples were centrifuged for $10 \mathrm{~min}$ at $16000 \times \mathrm{g}$ at $4{ }^{\circ} \mathrm{C}$. Pellets were discarded and lysates were analyzed for full length E-cadherin by Western blotting. For the detection of the soluble extracellular E-cadherin fragment, supernatants of infected cells were collected. Bacteria were harvested in sterile PBS supplemented and sonicated to prepare bacterial lysates. Protein amounts were measured using Bradford (RotiQuant, Carl Roth).

\section{SDS PAGE and western blotting}

$10 \mu \mathrm{g}$ of the bacterial lysates or $0.5 \mu \mathrm{g}$ recombinant proteins were separated by SDS-PAGE and stained using 1\% Coomassie Brilliant Blue G250 (BioRad). To investigate E-cadherin cleavage, $50 \mu \mathrm{g}$ of cell lysates or $100 \mu \mathrm{l}$ of supernatants were separated by SDS-PAGE and transferred onto nitrocellulose membranes. Monoclonal antibodies recognizing the extracellular domain (ab40772, Abcam) or intracellular domain (24E10, Cell Signaling) of Ecadherin were used to detect the NTF in supernatants or the loss of full length E-cadherin in whole cell lysates, respectively. $B$-actin was detected using a monoclonal antibody (Sigma Aldrich).

\section{Casein zymography}

$10 \mu \mathrm{g}$ of the bacterial lysates or $1 \mu \mathrm{g}$ recombinant proteins were separated by casein-containing SDS gels under non-reducing conditions. Subsequently, gels were renatured in $2.5 \%$ Triton X-100 and equilibrated in developing buffer as previously described [25]. Caseinolytic activity was visualized after staining with $0.5 \%$ Coomassie Blue R250 (BioRad).

\section{Sequence analysis}

Protein sequences from H. pylori HtrA (G2J5T2), EPEC DegP (B7UIK8), EPEC DegQ (B7UJW6), EPEC DegS (B7UJW7), S. Typhimurium HtrA (P26982), Y. enterocolitica DegP (P74978), P. mirabilis DegQ (B4EXL6), P. mirabilis DegS (B4EXL5) were retrieved from UniProt (Table 1). Sequence alignments were performed using Clustal Omega [35]. Protein domain prediction was performed using SignalP4.1 and SMART (simple modular architecture research tool) [36-38]. $\left(^{*}\right)$ indicates identical amino acids in all sequences, conserved amino acid substitutions are labeled with (:) and semi-conservative substitutions are marked with (.).

\section{Cloning, mutagenesis and protein purification}

Cloning, mutagenesis and protein purification was performed as described before [25]. Briefly, genes encoding $H$. pylori HtrA (HpHtrA aa 18-475), EPEC DegP (EpDegP aa 27-474), EPEC DegQ (EpDegQ aa 29-455), EPEC DegS (EpDegS aa 28-355), S. Typhimurium HtrA (StHtrA aa 27-475), Y. enterocolitica DegP (YeDegP aa 21-478), P. mirabilis DegQ (PmDegQ aa 31-463), $P$. mirabilis DegS (PmDegS aa 1-356) lacking predicted signal peptides were amplified. Primer sequences are shown in Table 1. PCR fragments flanked by restriction sites for BamHI/EcoRI ( $H p H$ trA, EpDegS, YeDegP and PmDegQ), BamHI/XmaI (HpHtrA) or EcoRI/XhoI (PmDegS) were ligated into pGEX-6P-1 (GE Healthcare) for the expression of N-terminally tagged GST fusion proteins. Generation of inactive HtrA proteases $\left(H p \mathrm{HtrA}^{\mathrm{S} 221 \mathrm{~A}}, E p \mathrm{DegP}^{\mathrm{S} 236 \mathrm{~A}}, E p \mathrm{DegQ}^{\mathrm{S} 214 \mathrm{~A}}, E p \mathrm{DegS}^{\mathrm{S} 201 \mathrm{~A}}\right.$, St $\left.\mathrm{HtrA}^{\mathrm{S} 237 \mathrm{~A}}, Y e \mathrm{HtrA}^{\mathrm{S} 238 \mathrm{~A}}, P m \mathrm{PegQ}^{\mathrm{S} 219 \mathrm{~A}}, P_{m D e g S^{\mathrm{S} 199 \mathrm{~A}}}\right)$ was performed by $\mathrm{S} \rightarrow \mathrm{A}$ mutations in the active center using a site directed mutagenesis kit (Agilent) (Table 1). E. coli BL21 has been transformed with generated constructs and purification of the proteins was performed as previously described [25]. In brief, transformed $E$. coli was grown in $300 \mathrm{ml} \mathrm{LB}$ medium to an $\mathrm{OD}_{600}$ of 0.6 and the expression was induced by the addition of $0.1 \mathrm{mM}$ isopropylthiogalactosid (IPTG). The bacterial culture was pelleted at $6000 \times \mathrm{g}$ for $30 \mathrm{~min}$ at $4{ }^{\circ} \mathrm{C}$ and lysed in $10 \mathrm{ml}$ PBS by sonication. The lysate was cleared by centrifugation and the supernatants were incubated with glutathione sepharose (GE Healthcare Life Sciences) at $4{ }^{\circ} \mathrm{C}$ overnight. GST-tagged proteins were cleaved with $180 \mathrm{U}$ Prescission protease (GE Healthcare Life Sciences) for $16 \mathrm{~h}$ at $4{ }^{\circ} \mathrm{C}$ to remove the GST tag. RseA (residues 121-216) fused to an $\mathrm{N}$-terminal $\mathrm{His}_{6}$-tag was kindly provided by Tim Clausen (IMP, Vienna) and has been described previously [39]. RseA was expressed in E. coli BL21 and purified via ProBond NiNTA sepharose (Invitrogen). RseA was washed and eluted with $250 \mathrm{mM}$ imidazole. All purified proteins were rebuffered in the respective cleavage buffer compatible with following cleavage experiments.

\section{Antibody production}

A polyclonal antibody recognizing $H p H$ trA was generated by the immunization of rabbits with recombinant $\mathrm{HpHtrA}$ (Paul-Ehrlich Institute, Langen, Germany). Polyclonal antibodies for the detection of St HtrA, $Y e$ DegP, $E p D e g P$ or $P m D e g Q$ were produced by immunization of rabbits with recombinant $S t \mathrm{HtrA}{ }^{\mathrm{S} 237 \mathrm{~A}}$, $Y e \operatorname{DegP}^{\mathrm{S} 238 \mathrm{~A}}, E p \operatorname{DegP}^{\mathrm{S} 236 \mathrm{~A}}$ and PmDegQ proteins (David's Biotechnology GmbH, Regensburg, Germany).

\section{In vitro cleavage assays}

For in vitro cleavage studies, $50 \mathrm{ng}$ of recombinant human E-cadherin (R\&D) was incubated with $500 \mathrm{ng}$ of 
Table 1 Proteins analyzed in this study

\begin{tabular}{|c|c|c|c|c|c|c|}
\hline Pathogen & Strain & Name & Uniprot $^{a}$ & Primer sequences ${ }^{\mathrm{b}}$ & Mutagenesis primer $^{c}$ & Reference \\
\hline Helicobacter pylori & Hp26695 & $\mathrm{HtrA}$ & $\mathrm{G} 2 \mathrm{~J} 5 \mathrm{~T} 2$ & $\begin{array}{l}\text { 5'-AAGGATCCGGCAATATCCAAATCCAGAGCATG-3' } \\
\text { 5'-AAGAATTCGACCCACCCCTATCATTTCACC-3' }\end{array}$ & $\begin{array}{l}\text { 5'-GCTTCCATCAATCCTGGAAATGCTGGCGGCGCTTTAATTGATAGC-3' } \\
\text { 5'-GCTATCAATTAAAGCGCCGCCAGCATTTCCAGGATTGATGGAAGC-3' }\end{array}$ & [25] \\
\hline \multirow[t]{3}{*}{ EPEC } & \multirow[t]{3}{*}{ E2348/69 } & DegP & B7UIK8 & $\begin{array}{l}\text { 5'-GGATCCGCTGAGACTTCTTCA-3' } \\
\text { 5'-GCCGGGTTACTGCATTAACAG-3' }\end{array}$ & $\begin{array}{l}\text { 5'-CAACCGGGGTAACGCAGGTGGTGCGTTG-3' } \\
\text { 5'-CAACGCACCACC } \underline{\text { GCGTTACCCCGGTTG-3' }}\end{array}$ & [15] \\
\hline & & DegQ & B7UJW6 & $\begin{array}{l}\text { 5'-GATCGGATCCATTCCAGGCCAGGTTGCCGC-3' } \\
\text { 5'-CTAGCTCGAGTAACGCATTAGTAGGTAGAG-3' }\end{array}$ & $\begin{array}{l}\text { 5'-CATTAACCGCGGTAACGCCGGCGGTGCACTGTTAAAC-3' } \\
\text { 5'-GTTAACAGTGCACCGCCGGCGTIACCGCGGTTAATG-3' }\end{array}$ & This work \\
\hline & & DegS & B7UJW7 & $\begin{array}{l}\text { 5'-GATCGGATCCAGCCTTAACCCGCTTCCAC-3' } \\
\text { 5'-CTAGGAATTCTIAGTTGGTCGCCGGATATT-3' }\end{array}$ & $\begin{array}{l}\text { 5'-CCATTAACCACGGTAACGCTGGCGGCGCGCTGG-3' } \\
\text { 5'-CCAGCGCGCCGCCAGCGTTACCGTGGTTAATGG-3' }\end{array}$ & This work \\
\hline Salmonella Typhimurium & NCTC 12023 & $\mathrm{HtrA}$ & P26982 & $\begin{array}{l}\text { 5'-GATCGGATCCGCTGAAACGTCCTCTTC-3' } \\
\text { 5'-CATGCTCGAGTIACTGCATCAGCAAATAAATAG-3' }\end{array}$ & $\begin{array}{l}\text { 5'-CCGTGGTAACGCCGGCGGCGCGCTGG-3' } \\
\text { 5'-CCAGCGCGCCGCCGGCGTIACCACGG-3' }\end{array}$ & This work \\
\hline Yersinia enterocolitica & ATCC 27729 & DegP & P74978 & $\begin{array}{l}\text { 5'-GATCGGATCCCCGGTTTCTTCTGTCGTTGC-3' } \\
\text { 5'-CTAGGAATCTTACTGCATCAGCAGATAGAG-3' }\end{array}$ & $\begin{array}{l}\text { 5'-GCAATTAACCGTGGTAACGCCGGTGGTGCATTGATCAATC-3' } \\
\text { 5'-GATTGATCAATGCACCACCGGCGTACCACGGTAATTGC-3' }\end{array}$ & This work \\
\hline \multirow[t]{2}{*}{ Proteus mirabilis } & \multirow[t]{2}{*}{ ATCC 29906} & DegQ & B4EXL6 & $\begin{array}{l}\text { 5'-GGATCCGCCCTGCCTTCGGTAA-3' } \\
\text { 5'-GAATTCTTAACGCGAGCTGTTACGTAA-3' }\end{array}$ & $\begin{array}{l}\text { 5'-GCATCAATTAACCGTGGTAACGCTGGTGGTGCTTTAGTTAATC-3' } \\
\text { 5'-GATTAACTAAAGCACCACCAGCGTIACCACGGTTAATTGATGC-3' }\end{array}$ & This work \\
\hline & & DegS & B4EXL5 & $\begin{array}{l}\text { 5'-GATCGAATTCATGTTAAGCAAGCTACTGCG-3' } \\
\text { 5'-CTAGCTCGAGCTATGACTCTGGCTGATATT-3' }\end{array}$ & $\begin{array}{l}\text { 5'-CAATTAATGAAGGAAATGCAGGGGGGGCACTGATTAATACTG-3' } \\
\text { 5'-CAGTATTAATCAGTGCCCCCCCTGCATTTCCTTCATTAATTG-3' }\end{array}$ & This work \\
\hline
\end{tabular}

NCTC National Collection of Type Cultures, ATCC American Type Culture Collection

${ }^{\mathrm{a}}$ sequences of HtrA proteins; ${ }^{b}$ restriction recognition sites are underlined; ' ${ }^{\mathrm{c}}$ substituted nucleotides are underlined 
recombinant proteases in $50 \mathrm{mM}$ Hepes $(\mathrm{pH} 7.4)$ containing $1 \mathrm{mM}$ EDTA at $37^{\circ} \mathrm{C}$ for $24 \mathrm{~h}$. As indicated, proteolytic inactive proteins were included as controls. Cleavage of E-cadherin was detected by Western blot analyses. To demonstrate EpDegS activity, $7 \mu \mathrm{g} E p D e g S$ was incubated with $9 \mu \mathrm{g}$ recombinant RseA protein in the presence of $100 \mu \mathrm{M}$ YFF (DNRLGLVYFF) activator peptide [40] for $16 \mathrm{~h}$ at $37{ }^{\circ} \mathrm{C}$ in $100 \mathrm{mM} \mathrm{NaPO}$ (pH 7.5), $200 \mathrm{mM} \mathrm{NaCl}, 5 \mathrm{mM} \mathrm{MgCl} 2,1 \mathrm{mM}$ DTT und $10 \%$ glycerol. Where indicated, $300 \mathrm{ng}$ E-cadherin was added. Aliquots of the samples were analyzed by Western blotting for E-cadherin cleavage, while RseA degradation was detected by coomassie-stained SDS PAGEs.

\section{Results}

H. pylori only harbors a DegP homolog, whereas EPEC, $S$. Typhimurium and $Y$. enterocolitica express DegP,
DegS and DegQ, and the genome of $P$. mirabilis contains DegQ and DegS. To analyze their capacity to induce E-cadherin ectodomain shedding during infection, epithelial cells were colonized with selected pathogens and E-cadherin cleavage was investigated through detection of the loss of full length E-cadherin $\left(\mathrm{E}-\mathrm{cad}^{\mathrm{FL}}\right)$ in whole cell lysates and the formation of the soluble $\mathrm{N}$ terminal fragment $\left(\mathrm{E}-\mathrm{cad}^{\mathrm{NTF}}\right)$ in the supernatants of infected cells. To demonstrate equal protein amounts in whole cell lysates, $\beta$-actin was shown. As reported previously [15], H. pylori (Fig. 1a) and EPEC (Fig. 1b) induced efficient E-cadherin shedding as monitored by increase of E-cad ${ }^{\mathrm{NTF}}$ and, partially, by the corresponding decrease of E-cad ${ }^{\mathrm{FL}}$ after indicated time periods of infection. Cells infected with $S$. Typhimurium showed an increased amount of the cleaved soluble E-cad ${ }^{\mathrm{NTF}}$ in supernatants after $6 \mathrm{~h}$ and after $8 \mathrm{~h}$. The amount of $\mathrm{E}$-cad ${ }^{\mathrm{FL}}$
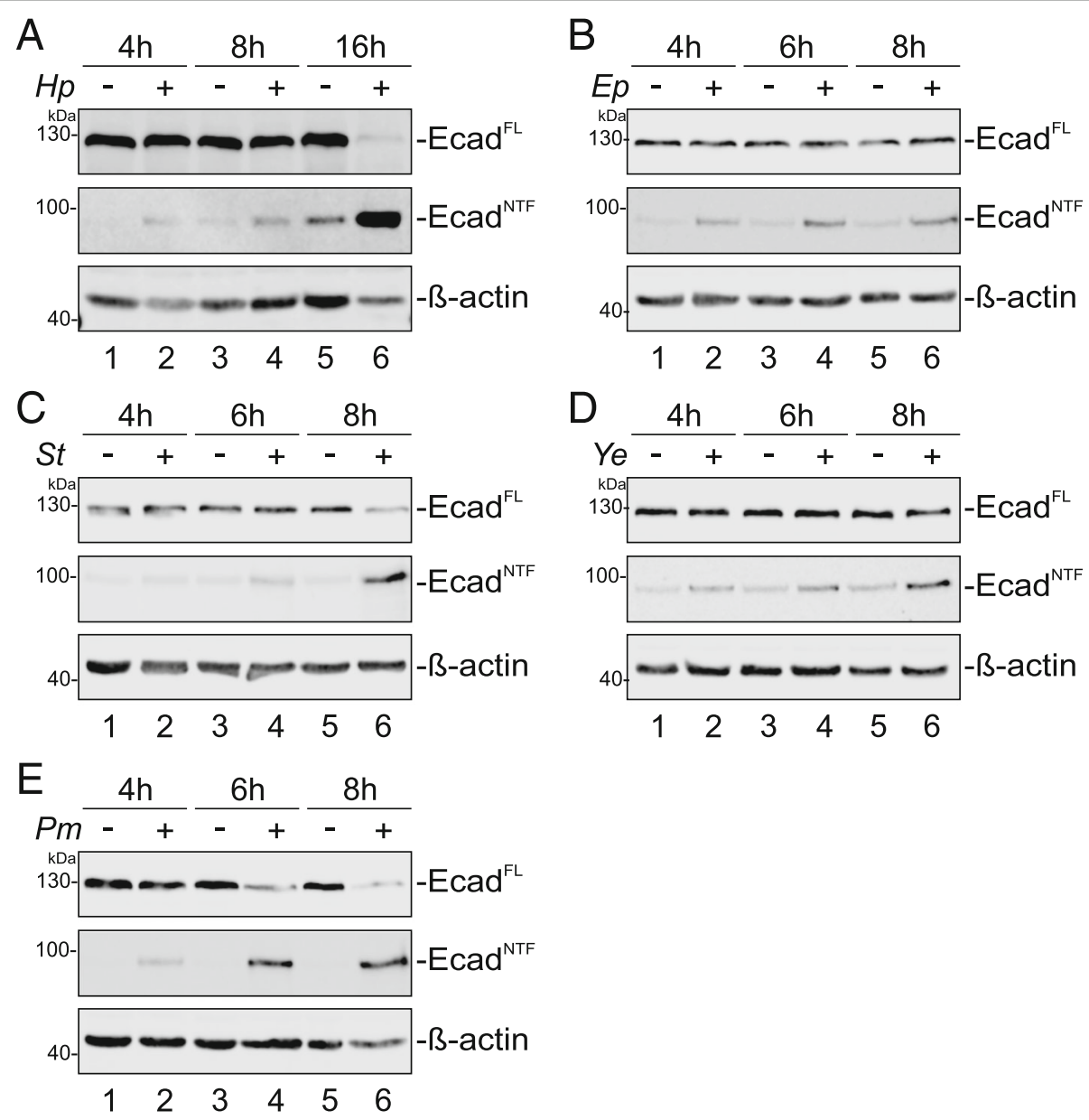

Fig. 1 E-cadherin cleavage during infection with Gram-negative pathogens. Human epithelial cells were infected with (a) H. pylori (Hp) at a MOI 100, (b) EPEC (Ep) at a MOI 5, (c) S. Typhimurium (St) at a MOI 5, (d) Y. enterocolitica (Ye) at a MOI 50 and (e) P. mirabilis (Pm) at a MOI 2. Different MOls were chosen after careful titration of infection doses to minimize bacterial overgrowth during infection. After indicated time periods, cells were lysed and full length E-cadherin (Ecad ${ }^{\mathrm{FL}}$ ) was detected by Western blot analyses using an antibody against the intracellular domain. Aliquots of supernatants were analyzed for the soluble extracellular E-cadherin fragment (Ecad ${ }^{\mathrm{NTF}}$ ) using an antibody against the extracellular domain. $\beta$-actin served as a loading control 
detectable in cell lysates decreased correspondingly (Fig. 1c) indicating that infections with $S$. Typhimurium induces E-cadherin ectodomain shedding during infection as well. Similar observations were made for cells infected with $Y$. enterocolitica (Fig. 1d). Compared to non-infected cells, E-cad ${ }^{\mathrm{FL}}$ slightly decreased, while E$\mathrm{cad}^{\text {NTF }}$ in the supernatants of infected cells appeared (Fig. 1d). As a Gram-negative uropathogen, P. mirabilis was included in this study. $P$. mirabilis induced a very strong decline of $\mathrm{E}-\mathrm{cad}^{\mathrm{FL}}$ in whole cell lysates and correspondingly, the amount of E-cad ${ }^{\mathrm{NTF}}$ drastically increased indicating an efficient cleavage of E-cadherin during colonization (Fig. 1e). These data imply that Ecadherin shedding occurs frequently during bacterial pathogenesis.

E-cadherin shedding can be induced by host proteases $[30,41]$ or by bacterial proteases, such as HtrA proteins $[15,27,30]$. To evaluate if HtrAs of $S$. Typhimurium, $Y$. enterocolitica, or P. mirabilis are expressed and capable of E-cadherin cleavage, we analyzed the expression of proteolytic active proteases by casein zymography in a first step. H. pylori expressed caseinolytically active monomeric and oligomeric HtrA at $50 \mathrm{kDa}$ and $>170 \mathrm{kDa}$, which have been previously identified by mass-spectrometry [25]. In lysates of $S$. Typhimurium, three different activities at $85 \mathrm{kDa}, 45 \mathrm{kDa}$ and $28 \mathrm{kDa}$ were observed. Four proteolytic activities $(90 \mathrm{kDa}$, $55 \mathrm{kDa}, 30 \mathrm{kDa}$ and $20 \mathrm{kDa}$ ) were found in $Y$. enterocolitica, while $P$. mirabilis exhibited caseinolytically active proteases of approximately $75 \mathrm{kDa}, 55 \mathrm{kDa}$ and $25 \mathrm{kDa}$. EPEC lysates contained proteolytic activities at $50 \mathrm{kDa}$, $30 \mathrm{kDa}$ and $20 \mathrm{kDa}$ (Fig. 2, upper panel), of which the $50 \mathrm{kDa}$ protease was identified as active DegP previously [15]. Equal protein amounts were demonstrated by a coomassie-stained SDS PAGE (Fig. 2, lower panel).

The serine protease HtrA or DegP is a highly conserved protease. Sequence alignments of HtrAs and DegPs of $H$. pylori ( HpHtrA), Y. enterocolitica (YeDegP), EPEC (EpDegP) and S. Typhimurium (StHtrA) demonstrated high similarities (Fig. 3). All HtrA/DegP proteases harbor a predicted $\mathrm{N}$-terminal signal peptide (orange), a proteolytic domain (green) with the catalytic triad containing a histidine, an aspartate and a serine (red). The protease domain was followed by two Cterminal PDZ domains (purple). In comparison to DegQ proteases (Additional file 1: Figure S1A), the LA loop (blue) in DegP proteases contained additional 20 amino acids [7]. Interestingly, the LA loop of $H$. pylori HtrA lacked 22 amino acids suggesting that $H$. pylori HtrA might be a DegQ protein rather than a DegP protein. However, $H p \mathrm{HtrA}$ shows a higher identity with $E p$ DegP (43\% identity, $\mathrm{E}=2 \mathrm{e}-87$ ) compared to the alignment of $H p \mathrm{HtrA}$ with EpDegQ (37\% identity, E = 8e-81), while a comparison of EpDegQ and PmDegQ uncovered an

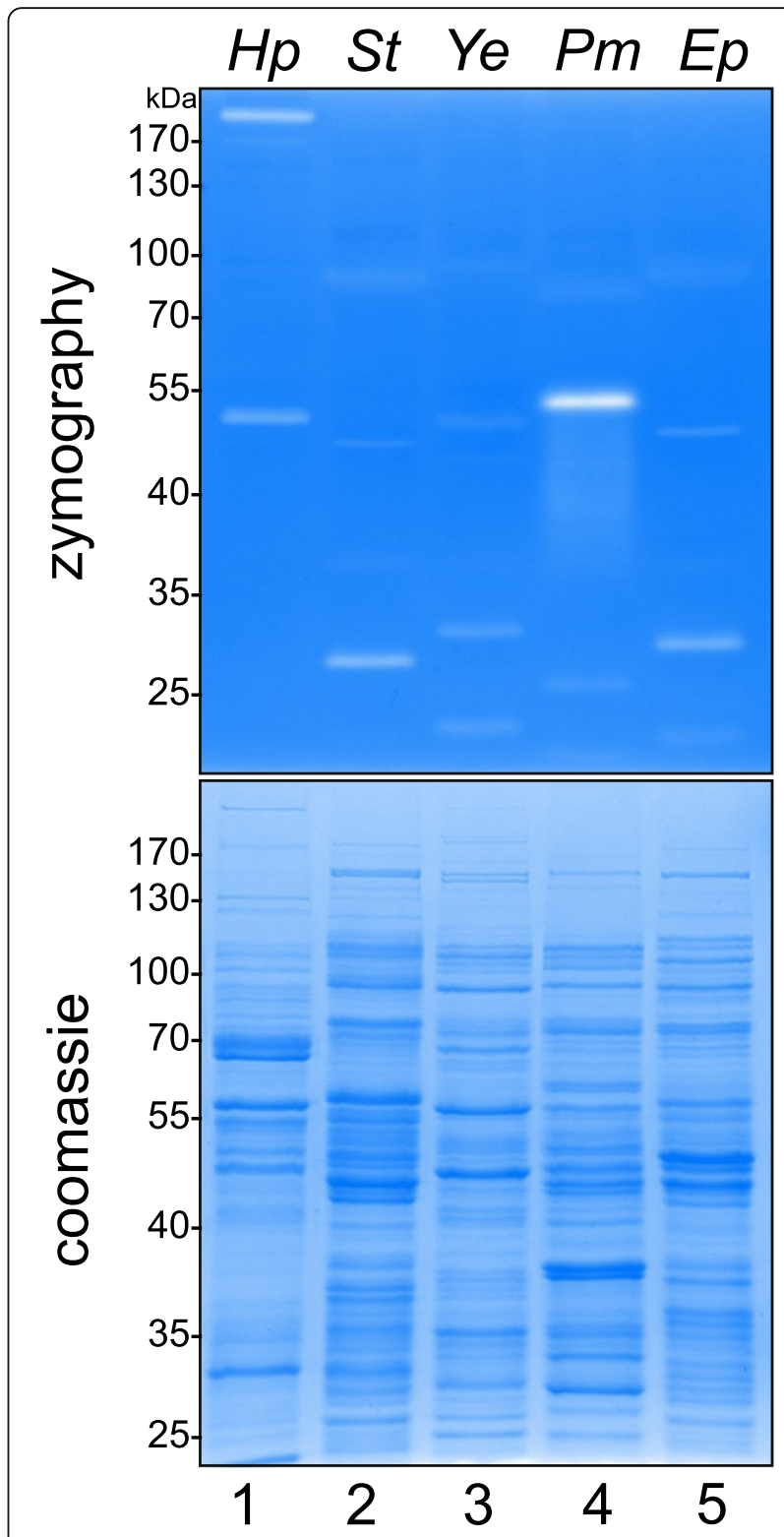

Fig. 2 Active proteases expressed by pathogens. H. pylori (Hp), EPEC (Ep), S. Typhimurium (St), Y. enterocolitica (Ye) and P. mirabilis (Pm) were sonicated and protein lysates were analyzed by casein zymography (upper panel). As a control, proteins were separated by SDS PAGE followed by coomassie staining to show equal protein loading (lower panel)

identity of 66\% (Additional file 1: Figure S1A). DegS has a different domain architecture $[1,3]$. DegS proteins often contain a transmembrane domain instead of a signal peptide and only one PDZ domain (Fig. 4a). Comparison of the amino acid sequence of $E p D$ DegS and $P m$ DegS (Additional file 1: Figure S1B) showed an identity of $59 \%(E=5 e-144)$. However, a signal peptide has been predicted for EpDegS and a putative transmembrane domain for PmDegS (Additional file 1: Figure S1B), which might indicate that they also have different 


\begin{tabular}{|c|c|}
\hline HpHtrA & MKKTLFISLALALSLNA GNIQIQSMPKVKERVSVPSKDDTIYSYHDSIKDSIKAVVNIST \\
\hline YeDegP & MKKTTLVLSALALSIGLAMG PVSSVVA--AET-ASSSSQQLPSLAPMLEKVMPSVVSINV \\
\hline EpDegP & MKKTTLALSALALSLGLALSPLSATAA--ETS-SATTAQQMPSLAPMLEKVMPSVVSINV \\
\hline \multirow[t]{2}{*}{ StHtrA } & MKKTTLAMSALALSLGLALSPLSATAA--ETSSSAMTAQQMPSLAPMLEKVMPSVVSINV \\
\hline & $.:: \star \quad:::::^{\star \star} \star^{\star} \ldots$ \\
\hline HpHtrA & EKKIKNNFIGGGVFNDPFFQQFFGDL $-\cdots,-\cdots$ \\
\hline YeDegP & EGSAQVS---NAGGI PPQFQQFFGDDSPFCQDGSPFQGSPMCQGGPGSRGGA PSKQDFRA \\
\hline EpDegP & EGSTTVN----TPRMPRNFQQFFGDDSPFCQEGSPFQSSPFCQGGLGGNGGG-QQQKFMA \\
\hline \multirow[t]{2}{*}{ StHtrA } & EGSTTVN----TPRMPRNF QQFFGDD SPFCQDGSPFQNSPFCQGGGNGNGG -QQQKFMA \\
\hline & $\star \star \star \star \star \star \star \star ~$ \\
\hline HpHtrA & LGSGVIIS-KDGYIVTNNHVIDGADKIKVTIPGSNKEYSATLVGTDSESDLAVIRITK-D \\
\hline YeDegP & LGSGVIIDAAKGYVVTNNHVVDNATKINVKLSD-GRSYEAKVIGKDPRTDIALIQLKDAK \\
\hline EpDegP & LGSGVIIDADKGYVVTNNHVVDNATVIKVQLSD-GRKFDAKMVGKDPRSDIALIQIQNPK \\
\hline \multirow[t]{2}{*}{ StHtrA } & LGSGVI IDAAKGYVVTNNHVVDNASVIKVQLSD-GRKFDAKVVGKDPRSDIALIQIQNPK \\
\hline & 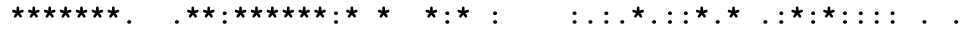 \\
\hline HpHtrA & NLPTIKFSDSNDISVGDLVFAIGNPFGVGESVTQGIVSALNKSGIGINS YENFIQTDASI \\
\hline YeDegP & NLTAIKIADSDQLRVGDYTVAIGNPYGLGETVTSGIVSALGRSGLNVENYENFIQTDAAI \\
\hline EpDegP & NLTAIKMADSDALRVGDYTVAIGNPFGLGETVTSGIVSALGRSGLNAENYENFIQTDAAI \\
\hline \multirow[t]{2}{*}{ StHtrA } & NLTAIKLADSDALRVGDYTVAIGNPFGLGETVTSGIVSALGRSGLNVENYENFIQTDAAI \\
\hline & 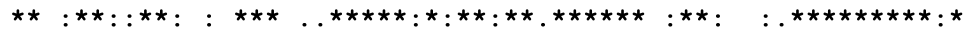 \\
\hline HpHtrA & NPGNSGGALIDSRGGLVGINTAIISKTGGNHGIGFAIPSNMVKDIVTQLIKTGKIERGYL \\
\hline YeDegP & NRGNSGGALINLNGELIGINTAILAPDGGNIGIGFAIPSNMVKNLTSQMVEFGQVKRGEL \\
\hline EpDegP & NRGNSGGALVNLNGELIGINTAILAPDGGNIGIGFAIPSNMVKNLTSQMVEYGQVKR GEL \\
\hline \multirow[t]{2}{*}{ StHtrA } & NRGNSGGALVNLNGELIGINTAILAPDGGNIGIGFAIPSNMVKNLTSQMVEYGQVKR GEL \\
\hline & 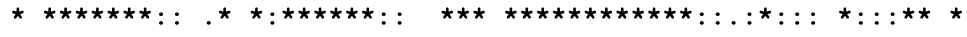 \\
\hline HpHtrA & GVGLQDLSGDLQNS --YDNKEGAVVISVEKDSPAKKAGILVWDLITEVNGKKVKNTNELR \\
\hline YeDegP & GIMGTELNSELAKAMKVDAQKGAFISQVLPKSAAAKAGIKAGDVIVSMNGKAINSFAGFR \\
\hline EpDegP & GIMGTELNSDLAKAMKVDAQRGAFVSQVLPNSSAAKAGIKAGDVITSLNGKPISSFAALR \\
\hline \multirow{2}{*}{ StHtrA } & GIMGTELNSELAKAMKVDAQRGAFVSQVMPNSSAAKAGIKAGDVITSLNGKPISSFAALR \\
\hline & 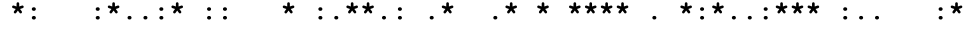 \\
\hline HpHtrA & NLIGSMLPNQRVTLKVIRDKKERAFTLTLAERKNPNKKETISAQNGAQGQLNGLQVEDLT \\
\hline YeDegP & AEIGTLPVGSKMTLGLLRDGKPVNVEVTLEQSSQTQVD--------SGNLYTGIEGAEL- \\
\hline EpDegP & AQVGTMPVGSKLTLGLLRDGKQVNVNLELQQSSQNQVD--------SSTIFNGIEGAEM- \\
\hline \multirow[t]{2}{*}{ StHtrA } & AQVGTMPVGSKISLGLLREGKAITVNLELQQSSQSQVD--------SSTIFSGIEGAEM- \\
\hline & 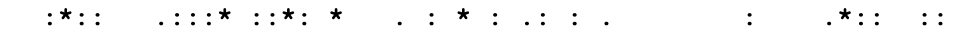 \\
\hline HpHtrA & QKTKRSMRLSDDVQGVLVSQVNENSPAEQAGFRQGNIITKIEEVEVKSVADFNHALEKYK \\
\hline YeDegP & -----SNSDVNGKKGVKVDSVKPGTAAARIGLKKGDVIMGVNQQPVQNLGELRKILDTK - \\
\hline EpDegP & -----SNKG--KDQGVVVNNVKTGTPAAQIGLKKGDVIIGANQQAVKNIAELRKVLDSK - \\
\hline \multirow[t]{2}{*}{ StHtrA } & -----SNKG--QDKGVVVSSVKANSPAAQIGLKKGDVIIGANQQPVKNIAELRKILDSK - \\
\hline & $: \star \star \star \ldots *: \quad: \star \star \quad: \star:::^{*}::^{*} \quad:: \quad *$ \\
\hline HpHtrA & GKPKRFLVLDLNQGYRIILVK-- \\
\hline YeDegP & --P-SVLALSIQRGDTSLYLLMQ \\
\hline EpDegP & --P-SVLALNIQRGDSTIYLLMQ \\
\hline StHtrA & --P-SVLALNIQRGDSSIYLLMQ \\
\hline
\end{tabular}

Fig. 3 Sequence alignment of the different HtrA/DegP proteins. Signal peptides (orange), proteolytic domains (green) containing the catalytic triad (red) and two PDZ domains (purple) of H. pylori HtrA ( $H p H t r A)$, Y. enterocolitica DegP (YeDegP), EPEC DegP (EpDegP) and S. Typhimurium HtrA (StHtrA) are indicated. The LA loop region is highlighted in blue

functions. To investigate the different bacterial HtrA/ DegP proteins, we cloned, overexpressed and purified DegP proteins from $H$. pylori $(H p)$, S. Typhimurium $(S t)$, $Y$. enterocolitica $(Y e)$, and EPEC $(E p)$ and analyzed the caseinolytic activity in casein zymography experiments (Fig. 4b). In P. mirabilis (Pm), DegP was not annotated; hence, the $\operatorname{deg} Q$ gene was cloned. Additionally, proteolytic inactive proteases $\left(H p \mathrm{HtrA}^{\mathrm{S} 221 \mathrm{~A}}, E p D e g \mathrm{P}^{\mathrm{S} 236 \mathrm{~A}}\right.$, $\left.S t \mathrm{HtrA}^{\mathrm{S} 237 \mathrm{~A}}, Y e \mathrm{HtrA}^{\mathrm{S} 238 \mathrm{~A}}, P m D e g \mathrm{Q}^{\mathrm{S} 219 \mathrm{~A}}\right)$ were generated by the exchange of the serine by an alanine in the active center. Recombinant wildtype proteases $\left(\mathrm{rHtrA}^{\mathrm{wt}}\right.$ ) and their corresponding inactive mutants $\left(\mathrm{rHtrA}^{\mathrm{SA}}\right)$ were examined by casein zymography (Fig. 4b, upper panel) and coomassie-stained SDS PAGE (Fig. 4b, lower panel). In fact, all $\mathrm{rHtrA}^{\mathrm{wt}}$ proteins were caseinolytically active to different extents. A strong activity was observed for $H p \mathrm{HtrA}^{\mathrm{wt}}$, St $\mathrm{HtrA}^{\mathrm{wt}}$ and $P m D e g \mathrm{Q}^{\mathrm{wt}}$, while $Y e \mathrm{HtrA}^{\mathrm{wt}}$ and $E p \mathrm{DegP}^{\mathrm{wt}}$ were less active. As expected, the proteolytic inactive $\mathrm{rHtrA}^{\mathrm{SA}}$ mutants did not show any activities (Fig. 4b, upper panel). In our previous studies, we already identified an auto-processed H. pylori HtrA (sHtrA, short HtrA) by mass-spectrometry [25] 


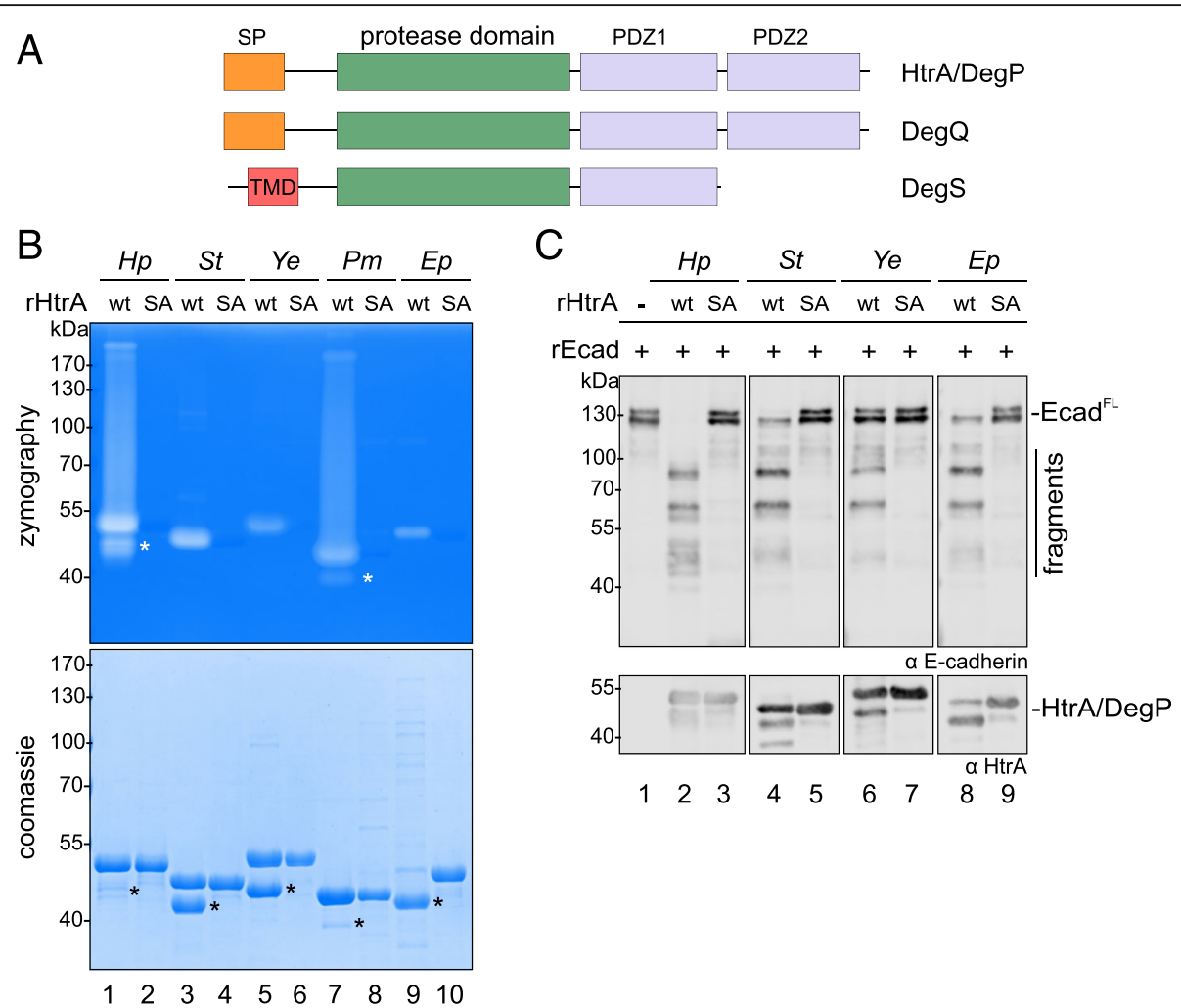

Fig. 4 Recombinant HtrA's/DegP's are proteolytically active and cleave E-cadherin in vitro. a Domain architecture of HtrA/DegP, DegQ and DegS proteins. SP, signal peptide (orange); protease domain (green); PDZ domains (purple); TMD, transmembrane domain (red). b The proteolytic activity of recombinant HtrA/DegP (rHtrA) wildtype proteins (wt) of H. pylori (Hp), S. Typhimurium (St), Y. enterocolitica (Ye), EPEC (Ep) and DegQ of P. mirabilis (Pm) was analyzed by casein zymography and compared to their corresponding inactive mutants (SA) (upper panel). Coomassie-stained SDS PAGES demonstrated equal protein loading (lower panel). Self-processed proteins (black asterisks) exhibiting proteolytic activity (white asterisks) are indicated. c Recombinant HtrAs/DegPs (wt) were investigated in in vitro cleavage assays using E-cadherin (E-cad ${ }^{\mathrm{FL}}$ ) as a substrate and compared with the corresponding inactive variants (SA) as a control. Fragments of E-cadherin were detected using an antibody recognizing the extracellular domain domain. HtrA/DegP proteins were detected using corresponding polyclonal antibodies

(Fig. 4b, lower panel, black asterisk), which was proteolytically active (Fig. 4b, upper panel, white asterisk). Auto-cleavage of DegP as part of a physiological process was also described for E. coli [42] and was also detected for $E p D e g P$ in this study (Fig. $4 \mathrm{~b}$, lower panel). In contrast to $H p H$ trA, auto-cleavage of EpDegP was almost complete, but led to an inactivation of DegP. A similar picture was observed for StHtrA and YeHtrA. Only the full length versions of $\mathrm{StH} \mathrm{HtA}$ and $\mathrm{YeH}$ trA were proteolytically active, while the truncated proteins exhibited no activities. This is in a slight contrast to PmDegQ. Comparable to $H p H \operatorname{trA}$, we detected large amounts of active full length and a smaller fraction of active autoprocessed PmDegQ (Fig. 4b). These data imply that auto-proteolytic processing leads to an inactivation of $S t \mathrm{HtrA}, \mathrm{YeHtrA}$ and $\mathrm{EpDegP}$, but not of $\mathrm{HpHtrA}$ or $P m$ DegQ. Recombinant HtrA/DegP proteins were further used for the production of polyclonal antisera recognizing the individual proteins (Additional file 1: Figure S2). In order to evaluate their E-cadherin cleavage capability, purified DegP homologs $\left(\mathrm{rHtrA}^{\mathrm{wt}}\right)$ and the corresponding inactive mutants $\left(\mathrm{rHtrA}^{\mathrm{SA}}\right)$ were then examined in in vitro cleavage experiments using recombinant E-cadherin (rEcad) as a substrate. Incubation of rEcad with rHtrA/ DegP from $H$. pylori, S. Typhimurium, $Y$. enterocolitica and EPEC induced the typical fragmentation pattern of rEcad indicating that the DegP homologs of the tested Gram-negative pathogens can directly target E-cadherin as a substrate. As expected, the inactive HtrA/DegP ${ }^{\text {SA }}$ proteins did not cleave rEcad (Fig. 4c). Polyclonal antibodies detecting the individual HtrA/DegP proteins (Additional file 1: Figure S2) showed equal loading of $\mathrm{HtrA} /$ DegP $^{\mathrm{wt}}$ and HtrA/DegP ${ }^{\mathrm{SA}}$ proteins (Fig. 4c).

Since it is unclear whether HtrA homologs have overlapping functions in bacteria, we compared the Ecadherin cleavage activity of the HtrA homologs DegP, DegQ and DegS from EPEC and P. mirabilis. Both, DegP and DegQ proteins, but not DegS or the corresponding inactive mutants from EPEC and $P$. mirabilis were caseinolytically active (Additional file 1: Figure S3A and Additional file 1: Figure S3B). Comparing the E-cadherin cleavage activity of the EPEC HtrA proteins DegP, DegQ 
and DegS revealed that $E p$ DegP cleaved E-cadherin more efficiently than EpDegQ. Compared to EpDegP, EpDegQ induced weak fragmentation of $\mathrm{E}$-cadherin in vitro. $E p$ DegS did not mediate E-cadherin cleavage. $\mathrm{HpHtrA}$ was used as a positive control. The polyclonal anti$E p$ DegP antibody detected $E p D e g P^{\text {wt }}$ and $E p D e g \mathrm{P}^{\mathrm{SA}}$ and showed weak cross-reactivity to EpDegQ and EpDegS (Fig. 5a). To underline the finding that DegQ proteases also cleave E-cadherin, we compared the E-cadherin cleavage activity of $E p$ DegP, $E p$ DegQ, $E p$ DegS with $P m$ DegQ and $P m$ DegS. In fact, $P m$ DegQ directly cleaved rEcad, which was comparable to EpDegP and EpDegQ (Fig. 5b). Corresponding to EpDegS, PmDegS did not fragment rEcad (Fig. 5b). It has been demonstrated that DegS activity requires stimulation by activator peptides [40]. The fact that recombinant DegS from EPEC is an active protease was demonstrated in an in vitro cleavage experiment using the DegS substrate RseA (Fig. 5c).
Upon stimulation with the YFF activator peptide [40], EpDegS efficiently degraded RseA (Fig. 5c, middle panel). In parallel, rEcad was added as indicated. However, rEcad was not targeted by active DegS (Fig. 5c, upper panel). These data underline that E-cadherin shedding is mainly mediated by bacterial DegP and DegQ homologs, while activated DegS failed to target Ecadherin as a substrate.

\section{Discussion}

HtrA proteases are crucially important for bacterial pathogenesis. Their periplasmic chaperone functions facilitate bacterial viability and survival by refolding and degradation of misfolded proteins under stress conditions $[1,3]$. Furthermore, HtrA proteins are also implicated in the modulation of pathogen-host interaction by processing of surface-presented virulence factors or adhesins $[14,16,17]$. Another important function was
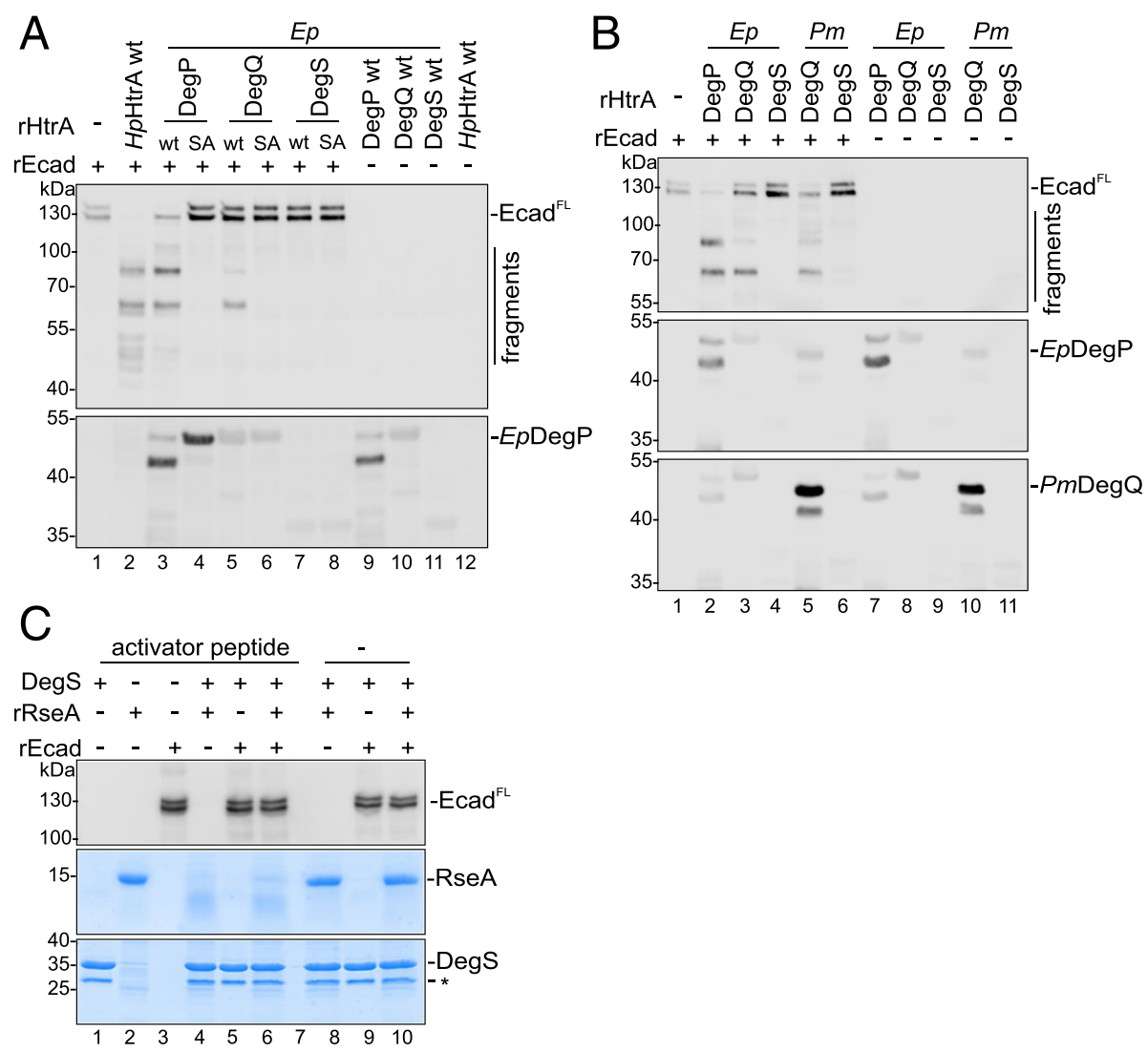

Fig. 5 DegP and DegQ, but not DegS cleave E-cadherin in vitro. a DegP, DegQ and DegS wildtype (wt) of EPEC (Ep) and the corresponding inactive mutants (SA) were tested in in vitro cleavage assays using E-cadherin ( $\mathrm{rEcad}$ ) as a substrate (upper panel). EpDegP $\mathrm{P}^{\mathrm{wt}}$ and $E p D e g \mathrm{P}^{\mathrm{SA}}$ were detected using anti-EpDegP antibody (lower panel). b The E-cadherin-cleavage activity of EPEC (Ep) DegP, DegQ and DegS was compared with the activity of $P$. mirabilis (Pm) DegQ and DegS. EpDegP and PmDegQ were detected using polyclonal antibodies. c The selective activity of EpDegS was shown in in vitro cleavage experiments using $7 \mu \mathrm{g}$ EpDegS and $9 \mu \mathrm{g}$ recombinant RseA (rRseA) as a substrate. To stimulate the activity of EpDegS, $100 \mu \mathrm{M}$ YFF activator peptide or equal amounts of diluent (-) were added as indicated. $300 \mathrm{ng}$ rEcad was included in the reactions where indicated. Aliquots of samples were analyzed by Western blotting to detect E-cadherin (upper pane) and the remaining sample was separated by SDS PAGE following coomassie staining to detect the degradation of RseA (middle panel) and EpDegS proteins (lower panel). The asterisk (*) indicates GST protein co-purified with the EpDegS protein 
observed for secreted or outer-membrane vesicleassociated HtrA from H. pylori and C. jejuni, which directly cleaves the extracellular domain of E-cadherin on host cells $[15,27,29,30]$. HtrA-mediated E-cadherin cleavage opens intercellular adherens junctions allowing bacterial transmigration across the epithelial barrier [15, 29, 30, 33]. Cleavage of E-cadherin has been additionally observed for HtrA expressed by EPEC and S. flexneri during infection of cultured epithelial cells and in vitro [15] indicating that HtrA-induced E-cadherin shedding represents a prevalent mechanism in bacterial pathogenesis. In contrast to $H$. pylori or C. jejuni, many pathogens express more than one HtrA homolog, namely DegP, DegQ and DegS and it is completely unclear, which of these homologs target E-cadherin. Therefore, we investigated the cleavage activity of the three different bacterial HtrA homologs and found that (i.) additional Gram-negative pathogens S. Typhimurium, $Y$. enterocolitica and $P$. mirabilis express E-cadherinfragmenting HtrA proteases and (ii.) that DegP and DegQ homologs, but not DegS, cleave E-cadherin.

The finding that DegP and DegQ, but not DegS, are active E-cadherin proteases is interesting since it indicates a specific and economical mechanism through which bacteria can interfere directly with host cells functions. Generally, the amino acid sequences of DegP and DegQ proteases show high similarities indicating conserved roles in bacteria. Sequence alignment revealed that $\mathrm{HpHtrA}$ lacks 22 amino acids in the LA loop leading to the assumption it could be a DegQ homolog rather than a DegP protein. However, $H p H$ trA exhibits a higher similarity with DegP proteins. Therefore, it remains vague whether $H p H$ trA represents a DegP or DegQ protein. From the literature, it is apparently not clear whether HtrA homologs have redundant functions. Consistently described, deletion of $\operatorname{deg} P$ led to a higher sensitivity of the bacteria toward elevated temperatures [43-45]. It has been previously suggested that DegQ can compensate for lacking DegP functions [10]. In other studies, $\operatorname{deg} P, \operatorname{deg} Q$ and $\operatorname{deg} S$ mutants did not show the same phenotype [46] suggesting that the HtrA homologs have different roles. Further, DegQ or DegS reexpression did not fully replace DegP functions in a knock-out mutant $[8,11]$ implying that DegP and DegQ have different roles in the bacterial periplasm. In our report, we found that only DegP from H. pylori, EPEC, S. Typhimurium, $Y$. enterocolitica, and DegQ proteases expressed by EPEC and P. mirabilis target E-cadherin as a substrate. Since these pathogens interfere with host cell functions via different mechanisms, it needs to be investigated in future, how HtrA-mediated E-cadherin cleavage contributes to the infections with the individual pathogens. Importantly, the opening of the intercellular space can facilitate the contact between pathogens and basolaterally expressed host factors or cells of the immune system. Interestingly, $P$. mirabilis does not express a DegP protein, but an extremely active DegQ protein. Furthermore, active DegP and DegQ proteases also induced a similar fragmentation pattern of E-cadherin indicating that they target identical calcium binding and substrate recognition sites, which have been recently identified for $H p H$ trA $[33,47]$. DegS proteases from EPEC and P. mirabilis failed to cleave E-cadherin in vitro. The domain architecture of the DegS proteins differs considerably. A transmembrane domain was predicted in PmDegS, while EpDegS contains a putative signal peptide. Following the highly conserved protease domain, DegS proteins harbor only one PDZ domain $[1,3]$. The fact that DegS did not cleave E-cadherin leads to the hypothesis that either the variation on the N-terminus or the second PDZ domain is implicated in the recognition and/or binding of E-cadherin. Based on these observations, we conclude that DegP and DegQ proteins, but not DegS exhibit an Ecadherin-cleaving activity. Our findings were mainly obtained from in vitro experiments as bacterial pathogens harboring genomic deletions of the individual $\operatorname{deg} P, \operatorname{deg} Q$ and $\operatorname{deg} S$ genes are not available to investigate the individual impact of HtrA proteins on bacterial pathogenesis. Still, in infection experiments using Gramnegative pathogens, which express different combinations of DegP, DegQ, and/or DegS, it became apparent that (i.) pathogens do not need DegS and (ii.) pathogens require at least DegP or DegQ for efficient E-cadherin cleavage.

\section{Conclusions}

E-cadherin cleavage during infection has been described for H. pylori, C. jejuni, EPEC and S. flexneri [15, 27, 29]. In this study, we added $S$. Typhimurium, $Y$. enterocolitica, and P. mirabilis to the collection of E-cadherintargeting pathogens. Those gastrointestinal bacteria colonize the epithelium of the intestine as the first barrier. E-cadherin shedding could promote bacterial virulence of these pathogens through providing entry through the polarized epithelium where specific virulence and pathogenic factors then interfere with host cell functions [31, 32]. Hence, it would be highly interesting to investigate the influence of the different HtrA homologs in their respective experimental animal models in vivo as HtrA proteins represent attractive therapeutic target molecules. The finding that the uropathogen $P$. mirabilis also induces E-cadherin shedding through its highly active DegQ protein also suggests a possible role for HtrA proteins in pathogens, which colonize nonintestinal epithelia. Therefore, future studies are necessary to study the function of HtrAs during the colonization of pathogens targeting the epithelium of other organs. 


\section{Additional file}

Additional file 1: Show an additional alignment of DegQ and DegS proteins (Figure S1), validation of anti-HtrA antibodies (Figure S2), and the activity of recombinant proteases (Figure S3). (PDF $1620 \mathrm{~kb}$ )

\section{Abbreviations}

DegP/Q/S: Periplasmic serine endoproteases; Dlg1: Drosophila disc large tumor suppressor; EPEC: Enteropathogenic escherichia coli; HtrA: High temperature requirement $A$; NTF: N-terminal fragment; PDZ: Postsynaptic density protein (PSD95); ZO-1: Zonula occludens-1 protein

\section{Acknowledgements}

We thank Markus Hell (Landeskliniken Salzburg) for providing Yersinia enterocolitica. We are also very grateful to Tim Clausen (IMP, Vienna) for the RseA plasmid and the DegS activator peptide.

\section{Funding}

The work of SW was supported by the grant P_24074 from the Austrian Science Fund (FWF).

\section{Availability of data and materials}

The datasets supporting the conclusions of this article are included within the article and its additional files.

\section{Authors' contributions}

Conceived and designed the experiments: CMA, GP, SW. Performed the experiments: MS, CMA, CG, GP, TPS. Wrote the paper: CMA, SW. All authors read and approved the final manuscript.

\section{Authors' information}

Not applicable.

\section{Competing interests}

The authors declare that they have no competing interests.

\section{Consent for publication}

Not applicable.

\section{Ethics approval and consent to participate}

Not applicable.

Received: 9 August 2016 Accepted: 1 December 2016

Published online: 08 December 2016

\section{References}

1. Clausen T, Kaiser M, Huber R, Ehrmann M. HTRA proteases: regulated proteolysis in protein quality control. Nat Rev Mol Cell Biol. 2011;12(3):152-62.

2. Skorko-Glonek J, Zurawa-Janicka D, Koper T, Jarzab M, Figaj D, Glaza P, Lipinska B. HtrA protease family as therapeutic targets. Curr Pharm Des. 2013;19(6):977-1009.

3. Hansen G, Hilgenfeld R. Architecture and regulation of HtrA-family proteins involved in protein quality control and stress response. Cell Mol Life Sci. 2013;70(5):761-75

4. Sawa J, Heuck A, Ehrmann M, Clausen T. Molecular transformers in the cell: lessons learned from the DegP protease-chaperone. Curr Opin Struct Biol. 2010:20(2):253-8

5. Krojer T, Sawa J, Schafer E, Saibil HR, Ehrmann M, Clausen T. Structural basis for the regulated protease and chaperone function of DegP. Nature. 2008: 453(7197):885-90

6. Spiess C, Beil A, Ehrmann M. A temperature-dependent switch from chaperone to protease in a widely conserved heat shock protein. Cell. 1999; 97(3):339-47.

7. Wrase R, Scott H, Hilgenfeld R, Hansen G. The Legionella HtrA homologue DegQ is a self-compartmentizing protease that forms large 12-meric assemblies. Proc Natl Acad Sci U S A. 2011:108(26):10490-5.

8. Waller PR, Sauer RT. Characterization of degQ and degS, Escherichia coli genes encoding homologs of the DegP protease. J Bacteriol. 1996;178(4): $1146-53$.
9. Figaj D, Gieldon A, Polit A, Sobiecka-Szkatula A, Koper T, Denkiewicz M, Banecki B, Lesner A, Ciarkowski J, Lipinska B, et al. The LA loop as an important regulatory element of the HtrA (DegP) protease from Escherichia coli: structural and functional studies. J Biol Chem. 2014;289(22):15880-93.

10. Kolmar H, Waller PR, Sauer RT. The DegP and DegQ periplasmic endoproteases of Escherichia coli: specificity for cleavage sites and substrate conformation. J Bacteriol. 1996;178(20):5925-9.

11. Bass S, Gu Q, Christen A. Multicopy suppressors of prc mutant Escherichia coli include two HtrA (DegP) protease homologs (HhoAB), DksA, and a truncated R1pA. J Bacteriol. 1996;178(4):1154-61.

12. Alba BM, Leeds JA, Onufryk C, Lu CZ, Gross CA. DegS and YaeL participate sequentially in the cleavage of RseA to activate the sigma (E)-dependent extracytoplasmic stress response. Genes Dev. 2002;16(16):2156-68.

13. Frees $D$, Brondsted $L$, Ingmer $H$. Bacterial proteases and virulence. Subcell Biochem. 2013:66:161-92.

14. Purdy GE, Fisher CR, Payne SM. ICSA surface presentation in shigella flexneri requires the periplasmic chaperones DegP, Skp, and SurA. J Bacteriol. 2007; 189(15):5566-73

15. Hoy B, Geppert T, Boehm M, Reisen F, Plattner P, Gadermaier G, Sewald N, Ferreira F, Briza P, Schneider G, et al. Distinct roles of secreted HtrA proteases from gram-negative pathogens in cleaving the junctional protein and tumor suppressor E-cadherin. J Biol Chem. 2012;287(13):10115-20.

16. Baek KT, Vegge CS, Brondsted L. HtrA chaperone activity contributes to host cell binding in campylobacter jejuni. Gut pathogens. 2011;3:13.

17. Brondsted L, Andersen MT, Parker $\mathrm{M}$, Jorgensen $\mathrm{K}$, Ingmer $\mathrm{H}$. The HtrA protease of campylobacter jejuni is required for heat and oxygen tolerance and for optimal interaction with human epithelial cells. Appl Environ Microbiol. 2005:71(6):3205-12.

18. Boehm M, Lind J, Backert S, Tegtmeyer N. Campylobacter jejuni serine protease HtrA plays an important role in heat tolerance, oxygen resistance, host cell adhesion, invasion, and transmigration. Eur J Microbiol Immunol. 2015:5(1):68-80

19. Heimesaat MM, Alutis M, Grundmann U, Fischer A, Tegtmeyer N, Bohm M, Kuhl AA, Gobel UB, Backert S, Bereswill S. The role of serine protease HtrA in acute ulcerative enterocolitis and extra-intestinal immune responses during campylobacter jejuni infection of gnotobiotic IL-10 deficient mice. Front Cell and Infect Microbiol. 2014;4:77

20. Heimesaat MM, Fischer A, Alutis M, Grundmann U, Boehm M, Tegtmeyer N, Gobel UB, Kuhl AA, Bereswill S, Backert S. The impact of serine protease HtrA in apoptosis, intestinal immune responses and extra-intestinal histopathology during campylobacter jejuni infection of infant mice. Gut pathogens. 2014;6:16.

21. Ingmer $\mathrm{H}$, Brondsted L. Proteases in bacterial pathogenesis. Res Microbiol. 2009;160(9):704-10.

22. Huston WM, Swedberg JE, Harris JM, Walsh TP, Mathews SA, Timms P. The temperature activated $\mathrm{Htr}$ A protease from pathogen Chlamydia trachomatis acts as both a chaperone and protease at $37^{\circ} \mathrm{C}$. FEBS Lett. 2007:581(18): 3382-6

23. Wu X, Lei L, Gong S, Chen D, Flores R, Zhong G. The chlamydial periplasmic stress response serine protease $\mathrm{CHtrA}$ is secreted into host cell cytosol. BMC Microbiol. 2011:11:87.

24. Patel P, De Boer L, Timms P, Huston WM. Evidence of a conserved role fo Chlamydia HtrA in the replication phase of the chlamydial developmental cycle. Microbes Infect. 2014;16(8):690-4.

25. Lower M, Weydig C, Metzler D, Reuter A, Starzinski-Powitz A, Wessler S, Schneider G. Prediction of extracellular proteases of the human pathogen helicobacter pylori reveals proteolytic activity of the Hp1018/19 protein HtrA. PLoS One. 2008;3(10):23.

26. Boehm M, Haenel I, Hoy B, Brondsted L, Smith TG, Hoover T, Wessler S, Tegtmeyer N. Extracellular secretion of protease HtrA from campylobacter jejuni is highly efficient and independent of its protease activity and flagellum. Eur J Microbiol Immunol. 2013:3(3):163-73.

27. Elmi A, Nasher F, Jagatia H, Gundogdu O, Bajaj-Elliott M, Wren B, Dorrell N. Campylobacter jejuni outer membrane vesicle-associated proteolytic activity promotes bacterial invasion by mediating cleavage of intestinal epithelial cell E-cadherin and occludin. Cell Microbiol. 2016;18(4):561-72.

28. Olofsson A, Vallstrom A, Petzold K, Tegtmeyer N, Schleucher J, Carlsson S, Haas R, Backert S, Wai SN, Grobner G, et al. Biochemical and functional characterization of helicobacter pylori vesicles. Mol Microbiol. 2010;77(6):1539-55.

29. Boehm M, Hoy B, Rohde M, Tegtmeyer N, Baek KT, Oyarzabal OA, Brondsted L, Wessler S, Backert S. Rapid paracellular transmigration of campylobacter 
jejuni across polarized epithelial cells without affecting TER: role of proteolytic-active HtrA cleaving E-cadherin but not fibronectin. Gut pathogens. 2012;4(1):1757-4749.

30. Hoy B, Lower M, Weydig C, Carra G, Tegtmeyer N, Geppert T, Schroder P, Sewald N, Backert S, Schneider G, et al. Helicobacter pylori HtrA is a new secreted virulence factor that cleaves $\mathrm{E}$-cadherin to disrupt intercellular adhesion. Embo Rep. 2010;11(10):798-804.

31. Backert S, Boehm M, Wessler S, Tegtmeyer N. Transmigration route of Campylobacter jejuni across polarized intestinal epithelial cells: paracellular, transcellular or both? Cell Commun signal: CCS. 2013;11:72.

32. Posselt $\mathrm{G}$, Backert $\mathrm{S}$, Wessler $\mathrm{S}$. The functional interplay of Helicobacter pylori factors with gastric epithelial cells induces a multi-step process in pathogenesis. Cell Commun Signal: CCS. 2013;11:77.

33. Schmidt TP, Perna AM, Fugmann T, Bohm M, Jan H, Haller S, Gotz C, Tegtmeyer N, Hoy B, Rau TT et al. Identification of E-cadherin signature motifs functioning as cleavage sites for Helicobacter pylori HtrA. Sci Rep. 2016;6:23264.

34. GloeckI S, Ong VA, Patel P, Tyndall JD, Timms P, Beagley KW, Allan JA, Armitage $C W$, Turnbull $L$, Whitchurch $C B$, et al. Identification of a serine protease inhibitor which causes inclusion vacuole reduction and is lethal to Chlamydia trachomatis. Mol Microbiol. 2013;89(4):676-89.

35. Sievers F, Wilm A, Dineen D, Gibson TJ, Karplus K, Li W, Lopez R, McWilliam H, Remmert M, Soding J, et al. Fast, scalable generation of high-quality protein multiple sequence alignments using Clustal Omega. Mol Syst Biol. 2011;7(539):75.

36. Letunic I, Doerks T, Bork P. SMART: recent updates, new developments and status in 2015. Nucleic Acids Res. 2015;43(Database issue):9.

37. Schultz J, Milpetz F, Bork P, Ponting CP. SMART, a simple modular architecture research tool: identification of signaling domains. Proc Natl Acad Sci U S A. 1998;95(11):5857-64.

38. Petersen TN, Brunak S, von Heijne G, Nielsen H. SignalP 4.0: discriminating signal peptides from transmembrane regions. Nat Methods. 2011;8(10):785-6. doi:10.1038/nmeth.1701.

39. Hasselblatt H, Kurzbauer R, Wilken C, Krojer T, Sawa J, Kurt J, Kirk R, Hasenbein S, Ehrmann M, Clausen T. Regulation of the sigmaE stress response by DegS: how the PDZ domain keeps the protease inactive in the resting state and allows integration of different OMP-derived stress signals upon folding stress. Genes Dev. 2007;21(20):2659-70.

40. Wilken C, Kitzing K, Kurzbauer R, Ehrmann M, Clausen T. Crystal structure of the DegS stress sensor: how a PDZ domain recognizes misfolded protein and activates a protease. Cell. 2004;117(4):483-94.

41. Schirrmeister W, Gnad T, Wex T, Higashiyama S, Wolke C, Naumann M, Lendeckel $\mathrm{U}$. Ectodomain shedding of E-cadherin and c-Met is induced by Helicobacter pylori infection. Exp Cell Res. 2009;315(20):3500-8.

42. Skorko-Glonek J, Zurawa D, Tanfani F, Scire A, Wawrzynow A, Narkiewicz J, Bertoli E, Lipinska B. The N-terminal region of HtrA heat shock protease from Escherichia coli is essential for stabilization of HtrA primary structure and maintaining of its oligomeric structure. Biochim Biophys Acta. 2003;1649(2):171-82.

43. Lipinska B, Fayet O, Baird L, Georgopoulos C. Identification, characterization, and mapping of the Escherichia coli htrA gene, whose product is essential for bacterial growth only at elevated temperatures. J Bacteriol. 1989;171(3):1574-84.

44. Li SR, Dorrell N, Everest PH, Dougan G, Wren BW. Construction and characterization of a yersinia enterocolitica O:8 high-temperature requirement (htrA) isogenic mutant. Infect Immun. 1996;64(6):2088-94.

45. Diaz-Torres ML, Russell RR. HtrA protease and processing of extracellular proteins of Streptococcus mutans. FEMS Microbiol Lett. 2001;204(1):23-8.

46. Mo E, Peters SE, Willers C, Maskell DJ, Charles IG. Single, double and triple mutants of salmonella enterica serovar typhimurium degP (htrA), degQ (hhoA) and degS (hhoB) have diverse phenotypes on exposure to elevated temperature and their growth in vivo is attenuated to different extents. Microb Pathog. 2006;41(4-5):174-82.

47. Schmidt TP, Goetz C, Huemer M, Schneider G, Wessler S. Calcium binding protects E-cadherin from cleavage by Helicobacter pylori HtrA. Gut pathogens. 2016;8:29.

\section{Submit your next manuscript to BioMed Central and we will help you at every step:}

- We accept pre-submission inquiries

- Our selector tool helps you to find the most relevant journal

- We provide round the clock customer support

- Convenient online submission

- Thorough peer review

- Inclusion in PubMed and all major indexing services

- Maximum visibility for your research

Submit your manuscript at www.biomedcentral.com/submit
Biomed Central 